A N N A L E S

UNIVER S T ATIS M A R A E C URIE-SKŁODOW K A

LUBLIN - POLONIA

VOL. XXXIII, 2

SECTIO J

2020

Uniwersytet Śląski w Katowicach. Wydział Sztuki i Nauk o Edukacji

\title{
MARIOLA HOLEKSA
}

ORCID: 0000-0002-9232-4795

m.w.holeksa@gmail.com

\section{Poszukiwanie akceptacji w subkulturach młodzieżowych}

Seeking Acceptance in Youth Subcultures

Propozycja cytowania: Holeksa, M. (2020). Poszukiwanie akceptacji w subkulturach młodzieżowych. Annales Universitatis Mariae Curie-Skłodowska. Sectio J, Paedagogia-Psychologia, 33(2), 169-178. DOI: http://dx.doi.org/10.17951/j.2020.33.2.169-178.

\section{STRESZCZENIE}

Niniejszy artykuł dotyczy poszukiwania akceptacji przez młodzież, która boryka się z wieloma trudnościami. Problemy w relacjach z rówieśnikami i brak zrozumienia ze strony rodziców oddziałują na poszukiwanie akceptacji poza najbliższym środowiskiem. Młodzi szukają akceptacji m.in. wśród subkultur młodzieżowych. Współcześnie zaszły w nich znaczne zmiany. Nie są to już silnie wykształcone grupy z jasno określonymi granicami. Zmiany, jakie zaszły we współczesnym społeczeństwie, dotknęły również subkultur młodzieżowych. Celem analizy było poszukiwanie odpowiedzi na pytanie kierujące, które zostało sformułowane następująco: Jak prezentuje się poczucie tożsamości w narracjach przedstawicieli subkultur młodzieżowych? W omawianych badaniach zastosowano metodę wywiadu narracyjno-biograficznego. Badaniami objęto pięć młodych kobiet. W opisanych tu badaniach jakościowych narratorki wskazały, że zmagały się z trudnymi relacjami z rodzicami i rówieśnikami oraz że to subkultura pozwoliła im na znalezienie zrozumienia.

Słowa kluczowe: subkultury młodzieżowe; poszukiwanie akceptacji; akceptacja

\section{WPROWADZENIE}

Brak akceptacji ze strony rówieśników oraz rodziców powoduje, że młodzi poszukują zrozumienia poza najbliższym środowiskiem. Akceptację można odnaleźć wśród takich grup, jak subkultury młodzieżowe, których przedstawicieli łączą wspólne zainteresowania czy postawy.

Człowiek, a zwłaszcza młody człowiek, potrzebuje poczucia przynależności, które jest przejawem tożsamości kształtowanej w oparciu o grupy, z którymi 
się identyfikuje bądź się od nich izoluje. Ważne jest zatem wykształcenie granic pomiędzy grupami oraz uzmysłowienie sobie dystansu występującego pomiędzy nimi (Nikitorowicz, 1995, s. 86).

W społeczeństwie istnieje wiele podziałów. Zgodnie z terminologią Ervinga Goffmana jednym z nich jest podział na „normalsa” i nosiciela piętna. Są to dwie role, które odgrywamy w swoim życiu. W danej grupie atrybuty mogą uchodzić za normalne, podczas gdy w drugiej już jednostkę wyróżniają i są postrzegane jako piętno. Właśnie te cechy, które są postrzegane jako piętno, mogą warunkować poczucie alienacji $\mathrm{w}$ grupie lub środowisku. Piętno może być związane z wyglądem, cechami charakteru czy pochodzeniem. Nasze atrybuty nie zawsze są więc zależne od nas (Goffman, 2005, s. 31-34). W środowisku przynajmniej niektórych subkultur młodzieżowych widoczne jest decydowanie się na zdobycie atrybutów (np. tatuażu, skaryfikacji ciała), które mogą być uznane za piętno we własnym środowisku pochodzenia. Co istotne, atrybuty te pozwalają na funkcjonowanie jako „normalny” w innej grupie.

Przemysław Piotrowski zauważa, że poczucie wyobcowania można pokonać na dwa sposoby. Pierwszy z nich ma charakter konstruktywny i jest związany $\mathrm{z}$ instytucjami terapeutycznymi lub z udzielaniem się w kreatywnych subkulturach. Drugi zaś wiąże się z różnego rodzaju patologiami, nałogami oraz grupami odrzucającymi normy i wartości społeczne. Przykładem takich grup mogą być subkultury dewiacyjne, które odznaczają się konfliktowym zachowaniem, jak np. szalikowcy (Piotrowski, 2003, s. 112-113).

Ważne jest zatem zwracanie uwagi na problemy, jakie mogą przeżywać młode osoby, ponieważ nie zawsze poszukiwanie akceptacji może przynieść pozytywny skutek. Niektóre grupy promują zachowania agresywne. Same subkultury młodzieżowe nie są już tak zwartymi grupami jak wcześniej, lecz nadal pozwalają jednoczyć się osobom o podobnych zainteresowaniach i stylu bycia.

\section{SUBKULTURY DAWNIEJ I WSPÓŁCZEŚNIE}

Na początku pragnę wyjaśnić pojęcie „subkultury”. Odwołuję się w tym miejscu do jednej z podstawowych definicji, która z kolei odnosi się do tradycyjnego pojmowania tego zjawiska. Zdaniem kulturoznawcy Mirosława Pęczaka „subkultura to względnie spójna grupa społeczna pozostająca na marginesie dominujących w danym systemie tendencji życia społecznego, wyrażająca swoją odrębność poprzez zanegowanie lub podważenie utrwalonych i powierzchownie akceptowanych wzorów kultury" (Pęczak, 1992, s. 4). Autor podkreśla odrębność przedstawicieli subkultur, którzy wyrażają sprzeciw wobec dominujących wzorców zachowań, wartości czy postaw.

Jeden z czołowych współczesnych badaczy subkultur, David Muggleton, określa tożsamość ich przedstawicieli jako „wieloraką i płynną” (Muggleton, 2004, s. 63). Liczne modyfikacje i zmiany cechują dzisiejsze subkultury. Ponadto człon- 
ków grup subkulturowych wyróżnia większy indywidualizm. Obecnie nie trzeba skupiać się wyłącznie na jednym stylu, można bowiem korzystać z wielu, zmieniać jedne na inne. Zgodnie z powyższą charakterystyką zaangażowanie w grupę nie jest już tak intensywne. Dawne subkultury od współczesnych różni również podejście do mediów, dziś jest ono bardziej pozytywne (Muggleton, 2004, s. 63-69). Media, a zwłaszcza internet, pozwalają na zdobywanie informacji o subkulturach oraz poznawanie innych przedstawicieli. Muggleton nazywa współczesne subkultury „postsubkulturami” (Muggleton, 2004, s. 63).

Inną cechą wyróżniającą współczesne subkultury jest podejście do buntu i sprzeciwu. Dawniej subkultury charakteryzowała kontestacja powszechnie obowiązujących wartości, ról społecznych, polityki czy całej kultury (Filipiak, 1999, s. 17-18). Zbyszko Melosik określił bunt w dzisiejszej subkulturze jako relikt przeszłości. Wiąże się to ze zmianami we współczesnych subkulturach (Melosik, 2016, s. 92).

Muggleton wymienił różnorodne procesy i zjawiska jako impulsy, które doprowadziły do zmian w subkulturach, a wśród nich dezintegrację współczesnego społeczeństwa oraz ograniczenie homogeniczności kultury dominującej, podczas gdy grupy subkulturowe charakteryzuje sprzeciw wobec tej kultury (Muggleton, 2004, s. 64). Granice pomiędzy kulturą wysoką a popularną ulegają zatarciu. Zauważalne jest modyfikowanie elementów kultury wysokiej na rzecz kultury popularnej i odwrotnie (Melosik, 2015, s. 34). Melosik wskazał także, iż współcześnie ludzie nie utożsamiają się tak silnie z grupą subkulturową. Występuje bardziej indywidualne podejście (Melosik, 2016, s. 92).

Zmiany, jakie zaszły w subkulturach, odpowiadają przemianom, jakie dokonały się w społeczeństwie. Zygmunt Bauman nazwał współczesne społeczeństwo „płynną nowoczesnością”. Określenie to nawiązuje do braku stałości oraz do niepewności, zaskoczeń, ciągłego podejmowania decyzji, które są typowe dla dzisiejszej codzienności (Bauman, 2007, s. 49-50). Dawne społeczeństwa tradycyjne były uporządkowane; każdy był świadom, jaką rolę ma odgrywać. Zdaniem Baumana „niecodzienność jest dziś codziennością” (Bauman, 2009, s. 77-93). Stąd współcześnie tożsamość nie służy już do jej przetrzymywania, lecz do eksponowania, wymieniania na inne oraz poszukiwania kolejnych. Współczesne społeczeństwo wymaga zmiennej i elastycznej tożsamości (Bauman, 2007, s. 84). Według Anthony’ego Giddensa z kolei dzisiejsza tożsamość jest refleksyjna, czyli to my sami ją kształtujemy (Giddens, 2010, s. 107).

\section{METODOLOGICZNE PODSTAWY BADAŃ WŁASNYCH}

Zgodnie z terminologią Krzysztofa Rubachy w swoich badaniach jako metodę zbierania danych zastosowałam wywiad indywidualny i niekierowany, a dokładnie wywiad narracyjno-biograficzny. Celem takiego wywiadu jest poznanie życia badanej osoby, która podczas rozmowy opowiada swoją historię (Rubacha, 
2008, s. 136). Poszukiwałam odpowiedzi na pytanie kierujące, które sformułowałam następująco: Jak prezentuje się poczucie tożsamości w narracjach przedstawicieli subkultur młodzieżowych?

Wywiad narracyjno-biograficzny wiąże się ze strategią badań jakościowych, które umożliwiają większe skupienie się na badanych jednostkach oraz poznaniu kontekstu badanego zjawiska (Rubacha, 2008, s. 136). Skorzystałam również ze wskazówek Gabriele Rosenthal i podzieliłam wywiad na dwie części. Na początku zadałam pytanie wstępne, w następnej kolejności miała miejsce autoprezentacja biograficzna respondenta. Po zakończonej narracji zadawałam wcześniej przygotowane pytania narracyjne zewnętrzne i wewnętrzne. Hipotezy oraz hipotezy uzupełniające zostały przeze mnie sformułowane podczas analizy sekwencyjnej. Jest to zgodne $\mathrm{z}$ abdukcją w ujęciu Charlesa Sandera Peirce'a (Rosenthal, 2012, s. 184-195).

Tabela 1. Charakterystyka grupy badanej

\begin{tabular}{|c|c|c|c|}
\hline Narratorka & $\begin{array}{c}\text { Rok } \\
\text { urodzenia }\end{array}$ & $\begin{array}{c}\text { Miejsce urodzenia } \\
\text { i wychowania }\end{array}$ & Aktualne miejsce zamieszkania \\
\hline Osoba A & 2000 & Duże miasto & Duże miasto \\
\hline Osoba B & 1999 & Wieś & Miasto \\
\hline Osoba C & 1998 & Miasto & Miększe miasto \\
\hline Osoba D & 1989 & Miasto & Miasto \\
\hline Osoba E & 1994 & $\begin{array}{c}\text { Urodziła się w mieście, } \\
\text { wychowywała na wsi }\end{array}$ & \\
\hline
\end{tabular}

Źródło: opracowanie własne.

Grupa badana składała się z pięciu narratorek, które łączyła subkultura metalowa. Dwie utożsamiały się z nią w przeszłości, a pozostałe nadal się z nią identyfikują. Jedna z rozmówczyń utożsamiała się wówczas bardziej z subkulturą gotycką, inna z punkiem, a dwie eksperymentowały wcześniej z punkiem. Badania były w pełni anonimowe.

\section{ANALIZA BADAŃ DOTYCZĄCYCH SUBKULTUR MLODZIEŻOWYCH A POSZUKIWANIE AKCEPTACJI}

Przeprowadzone badania pozwoliły na określenie przynajmniej niektórych przyczyn problemów w kontaktach narratorek z rówieśnikami, które mogły zintensyfikować poczucie wyobcowania $\mathrm{w}$ grupie. W badanych przypadkach można zauważyć, że inne zainteresowania oraz styl mogą stanowić problem w kontaktach z rówieśnikami i pogłębiać poczucie wyobcowania z grupy. Samo utożsamianie się z subkulturą również może negatywnie oddziaływać na relacje z rówieśnikami.

W swoich opowieściach narratorki zwróciły uwagę na problemy, z jakimi musiały się zmierzyć. W badanych przypadkach wystąpiły: poczucie odrzucenia, 
problemy z nieustającą kontrolą i dyscypliną ze strony rodziców, brak wsparcia ze strony rodziców, rówieśników i nauczycieli. Problemy te musiały wpływać na samopoczucie młodej osoby.

Na poczucie własnej wartości silnie oddziałuje środowisko dziecka. Znaczenie mają sukcesy i porażki, porównywanie ich do osiągnięć innych oraz podobieństwo przekonań, wzorców i postaw. Ważne są też oczekiwania rodziców i rówieśników oraz oceny najbliższego otoczenia, w tym nauczycieli. Na poczucie wartości pozytywny wpływ wywiera akceptacja oraz wspieranie dziecka przez osoby dla niego ważne (Brzezińska, Appelt, Ziółkowska, 2016, s. 216-217).

$\mathrm{W}$ okresie adolescencji relacje z rówieśnikami o zbliżonych przekonaniach i wartościach zaspokajają poczucie akceptacji oraz zapewniają bezpieczeństwo, a co za tym idzie oddziałują pozytywnie na rozwój (Brzezińska i in., 2016, s. 262). Bunt młodzieży wynikający z alienacji łączy się nie tylko z zachowaniami o charakterze dewiacyjnym, lecz także z postawami kreatywnymi. Przykładem takich działań mogą być wolontariat, aktywność kulturalna i społeczna czy działalność w grupach religijnych (Tomaszek, Tucholska, 2012, s. 165).

Przeprowadzone wywiady wykazały, że poczucie inności i brak akceptacji ze strony rówieśników oraz rodziców powodują poszukiwanie zrozumienia w innym środowisku. Jedną z możliwości odnalezienia akceptacji mogą być właśnie subkultury. Pragnę zwrócić uwagę, że rozmówczynie w większości same podkreślały trudne relacje z rówieśnikami i rodzicami w pierwszej części wywiadu, dlatego można wnioskować, iż były one dla nich bardzo ważne.

Przejdę teraz do charakterystyki relacji narratorek z rówieśnikami i rodzicami. Pierwsza z nich wskazała, że jest osobą nieśmiałą, wrażliwą, a takie osoby staja się ofiarami ot tak. Podkreśliła również, że interesuje się mrokiem i horrorami. Relacje z rówieśnikami w szkole podstawowej określiła jako najgorsze, jakie sobie można wyobrazić. W gimnazjum nadal miała problem z niestałością i otwarciem się na innych, pojawiło się też wyśmiewanie przez rówieśników. Pomimo poczucia odrzucenia badana osoba stwierdziła, że czuła się lepiej w gimnazjum niż w szkole podstawowej.

Narratorka na początku nie wyrażała swojej przynależności do subkultury poprzez wygląd zewnętrzny. Wówczas skupiała się głównie na wewnętrznym przeżywaniu. Jak wspomniała, przez nieśmiałość dopiero w liceum zdecydowała się na zewnętrzne pokazanie swojej przynależności do subkultury gotyckiej. Narratorka wskazała, że uzewnętrznienie sprawiło jej ulgę oraz spełniła swoje marzenie. Wywołało to jednak szok rówieśników i stało się pretekstem do żartów. Obecnie narratorka uczęszcza do liceum. Choć z częścią rówieśników nie darzy się sympatią, to zawarła kilka przyjaźni. Można zauważyć, że znalazła akceptację w subkulturze, ale nie do końca u rówieśników, a bycie członkiem subkultury stało się tematem do żartów i śmiechów. Wprawdzie przyznała, że tym się nie przejmuje, lecz słowa te musiały zapisać się w jej pamięci. 
Następujące zdanie narratorki podkreśla rolę rówieśników: Tak jakby mrok byt we mnie od zawsze, miłość do horrorów itp., tylko ludzie to we mnie zaostrzyli i popychali mnie w tamtym kierunku, ludzie ksztatca ludzi, przez co powstaje coś nowego, na przyktad cecha, zamitowanie, zachowanie lub to się zaostrza. Można zauważyć, że po części to rówieśnicy, odrzucając, popychali ją coraz mocniej w stronę subkultury, w której czuła się akceptowana.

Narratorka nie mówiła wiele o rodzicach czy o trudnych relacjach z nimi. O niepełnej akceptacji ze strony rodziców mogą świadczyć następujące słowa: Co do rodziców to nie widzieli mnie w takim wydaniu, tylko z Instagrama, zawsze do szkoły chowam się przed nimi i mi się na razie udaje.

Druga narratorka ma styczność z subkulturą już od urodzenia, ponieważ wychowuje się w rodzinie, w której ojciec i wujkowie utożsamiają się z subkulturą metalową. Badana nastolatka nie czuła się akceptowana przez rówieśników w szkole podstawowej oraz gimnazjum ze względu na swoje zainteresowania i styl bycia. Od dziecka inaczej się ubierała i słuchała metalu. Wyznała, że nie spędzała wiele czasu z rówieśnikami, tylko oddawała się m.in. nauce i czytaniu książek. Warto zaznaczyć, że uczyła się bardzo dobrze. Na wsi brakowało osób do niej podobnych. Po ukończeniu gimnazjum zdecydowała się opuścić rodzinną wieś i rozpocząć naukę w liceum w mieście. To właśnie tu znalazła ludzi o podobnych zainteresowaniach oraz innych przedstawicieli subkultur. Narratorka podkreśliła, że była to dobra decyzja, ponieważ w swojej miejscowości nie potrafiła znaleźć osób o podobnych zainteresowaniach. Można zatem stwierdzić, iż odnalazła akceptację wśród innych przedstawicieli subkultury po opuszczeniu wsi. Narratorka wspomniała również, że zmagała się z depresją i miała myśli samobójcze. Wtedy uciekała w muzykę, która - jak wyznała - trzymała ją przy życiu.

Z jednej strony ojciec i wujkowie, którzy utożsamiają się z subkulturą metalowców, mieli duży wpływ na jej zainteresowania i poczucie tożsamości, z drugiej zaś matka nie utożsamia się z subkulturą. Zapewne w jakiejś mierze dlatego narratorka przyznała, iż nie czuła wystarczającego wsparcia z jej strony.

$\mathrm{W}$ trzecim przypadku dużą rolę odgrywały trudne relacje z rodzicami, którzy nadmiernie kontrolowali córkę, w efekcie czego codziennie dochodziło do awantur. Ponadto matka nie była względem niej ciepła ani wyrozumiała, a nawet stosowała kary cielesne. Wymagano od niej perfekcyjnego wykonywania zadań. Jak twierdzi narratorka: Od urodzenia moja mama przelewała na mnie swoje ambicje. Wraz z dorastaniem zwiększała się kontrola. Do zmian doszło w liceum, ponieważ wtedy dziewczyna spędzała więcej czasu poza domem. Rodzice stali się bardziej wyrozumiali.

Narratorka nie miała również wsparcia ze strony grupy rówieśniczej. Już w szkole podstawowej czuła się wyrzutkiem. Jak stwierdziła, była dojrzalsza od rówieśników i do nich po prostu nie pasowała. Badana czuła się nielubiana, wszystkim się przejmowała, przytyła. Kontakty z grupą rówieśniczą zmieniły się 
w drugiej klasie gimnazjum, ponieważ zawarła przyjaźnie z przedstawicielami subkultury metalowej: Czułam się z nimi dobrze. Nikt nie oceniat wygladu. Nikogo nie obchodziło, czy lubia mnie inni, a i muzykę pokochałam. Z muzyką metalową zetknęła się wcześniej, za sprawą ojca. Następnie poznała ludzi, do których stopniowo zaczęła się dopasowywać. W liceum poprawiły się relacje z rówieśnikami: Tam też poznałam moich obecnych przyjaciót. Byłam coraz bardziej pewna siebie. Ludzie mnie zaczęli akceptować.

Kiedy wyprowadziła się od ciągle kontrolujących ją rodziców, przeżyła załamanie nerwowe. Narratorka wskazała, iż zdaniem jej psychiatry: Organizm poczut się bezpiecznie $i$ wyrzucit z siebie mur, który zbudowałam $i$ wreszcie emocje wyszły. Dziś - jak stwierdziła - poradziła sobie z załamaniem nerwowym i czuje się szczęśliwa.

W przypadku czwartej narratorki w dzieciństwie rodzice nie zabraniali jej niczego. Matka chodziła z nią na koncerty, a ojciec kupował jej płyty. Jednak relacje z rodzicami z czasem stały się napięte. Swoją rodzinę określiła następująco: Trzy uparte, nerwowe osoby. Przez częste choroby spędzała dużo czasu w domu. Ze względu na pracę i zmęczenie rodzice nie poświęcali jej zbyt wiele czasu, a nie miała też nikogo do zabawy. Zainteresowały ją płyty winylowe i kasety video. Już jako dziecko słuchała płyt z muzyką z lat 70. i 80. Oglądała również filmy z kaset video. Jak podkreśliła: Wtedy po raz pierwszy zetknęłam się z twórczościa Queen, Pink Floyd czy Aerosmith. Rodzice prawie w pełni zaakceptowali przynależność córki do subkultury, choć nie zakończyła się ona wraz z okresem dorastania. Punktem sporu może być jedynie jej wygląd, a dokładniej czarny kolor ubrań. Obecnie swoje relacje $\mathrm{z}$ rodzicami badana uznaje za dobre.

Relacje z rówieśnikami tej narratorki były dość napięte. W szkole podstawowej czuła się intruzem. Jedną z przyczyn tego stanu rzeczy było uczęszczanie do szkoły niezgodnie z rejonem. Koledzy z klasy znali się między sobą z okolicy i przedszkola. Badana wspomniała, iż była spokojnym dzieckiem, miała inne zainteresowania, zatem niewiele było tematów do rozmów z rówieśnikami. Problemem w kontaktach z rówieśnikami okazał się również zawód matki - była policjantką. Warto podkreślić, że ze strony nauczycieli nie otrzymała pomocy, wsparcia ani zrozumienia. Uważali oni, że problemy z rówieśnikami to wina narratorki i musiała swoim zachowaniem sprowokować rówieśników. Problemy w środowisku szkolnym spotęgowało poczucie wyobcowania w grupie. Narratorka przyznała się, że miała incydent z samookaleczeniem.

Badana osoba wskazała, że w gimnazjum było ciut lepiej oraz pierwsze kontakty z rówieśnikami, wygłupy, oczywiście konflikty, jednak można powiedzieć, że były to typowe relacje między rówieśnikami. Można stwierdzić, że gimnazjum było dla niej przełomowym okresem. Wtedy zmieniła styl i zaczęła identyfikować się z subkulturą. Zawarła znajomości z osobami o podobnych muzycznych zainteresowaniach. Narratorka czuła także, że rówieśnicy byli bardziej otwarci 
i tolerancyjni, a relacje $\mathrm{z}$ rówieśnikami w liceum określiła jako podobne do tych z gimnazjum. Stwierdziła, że nie miała problemów z rówieśnikami, miała opinię takiej, co żyje w swoim świecie, ma jakieś hobby i na tym się skupiam, a że dało się ze mna rozmawiać.

Inaczej wyglądała sytuacja w przypadku ostatniej narratorki, która uznała swoje relacje z rówieśnikami w szkole podstawowej za dobre. Problem mogło stanowić uczęszczanie przez nią do szkoły poza rejonem zamieszkania, dlatego nie miała częstych kontaktów z rówieśnikami poza szkołą. Przyznała jednak, że nie czuła się wtedy odrzucona przez grupę z tego powodu. Zabawę z rówieśnikami zastąpiła czytaniem książek i rysowaniem.

Odmienność tego przypadku od poprzednich tkwi przede wszystkim w tym, że narratorka poznawała subkulturę metalowców wraz z rówieśnikami. Za pośrednictwem kolegi poznała piosenki zespołów metalowych. Wówczas ze znajomymi bardzo dużo eksperymentowaliśmy i rozmawialiśmy, dzieliliśmy się swobodnie wszystkim (...). Dzieliliśmy się muzyka, nosiliśmy się podobnie. Narratorka zaznaczyła również, że szkoła tolerancyjnie podchodziła do tego typu eksperymentów.

Po początkowo dobrych relacjach $\mathrm{z}$ rówieśnikami kryzys pojawił się $\mathrm{w}$ liceum. Był to dla niej bardzo trudny okres. Po szkole podstawowej i gimnazjum na wsi zdecydowała się na liceum w mieście. Między innymi za namową matki wybrała profil medyczny. Po pewnym czasie okazało się, że interesuje ją tylko jeden przedmiot - język polski; zaczęła wagarować. Relacje z rodzicami były wówczas już napięte. Ucieczką stało się pisanie wierszy, czytanie oraz treningi. Jej najlepsza przyjaciółka po pobycie w szpitalu psychiatrycznym zmieniła szkołę. Narratorka nie miała zatem wsparcia ani rodziców, ani rówieśników. Stwierdziła jednak, że nie czuła się odrzucona przez rówieśników: $Z$ wieloma osobami się zwyczajnie nie lubiłam albo nie miałam o czym rozmawiać, ale nic poza tym. Badana podkreśliła, że nie utrzymywała kontaktu z żadną osobą z liceum. Zmagała się też z problemami z wagą, na zmianę chudła i tyła. W liceum przestała udzielać się w subkulturze metalowej: Dopiero później odegrała znaczaca rolę w odkrywaniu siebie na nowo. Na zawieszenie udziału w subkulturze wpłynął przede wszystkim ciagły brak czasu, niedospanie, ogromny poziom stresu. Ograniczenie kontaktów też mogło mieć na to wpływ.

Nie do końca dobry wybór profilu klasy w liceum, konflikty z rodzicami, wagary, brak dawnych przyjaciół, problemy z wagą, stres to kłopoty, z jakimi wówczas się zmagała. Wtedy cały czas ptakałam, w ruch szły żyletki. Badanej udało się uporać z problemami m.in. dzięki muzyce. Nadrobiła zaległości w nauce i rozpoczęła studia. Wróciła również do subkultury metalowej, z którą utożsamia się do dzisiaj.

W tym przypadku można stwierdzić, że rodzice nie zawsze potrafią w pełni zaakceptować utożsamianie się swojego dziecka z subkulturą. Relacje z rodzicami nie układały się dobrze już od szkoły podstawowej, a w gimnazjum jeszcze się pogorszyły: $W$ gimnazjum natomiast zaczęłam bardzo wyraźnie mieć własne 
zdanie, które niekoniecznie przypadło im do gustu, zwłaszcza w wątku subkultur. Można zauważyć, że przynależność do subkultury wpłynęła negatywnie na relacje z rodzicami. Uległy one poprawie dopiero wraz z wyprowadzką rozmówczyni na studia. Rodzice zaakceptowali z czasem identyfikowanie się córki z subkulturą, jednak nadal problemem może być dla nich wygląd córki, podobnie jak to było w przypadku poprzedniej narratorki.

U badanych osób poczucie odrzucenia i brak wsparcia ze strony rówieśników oraz rodziców może negatywnie oddziaływać na samopoczucie. Zwłaszcza w przypadku czterech pierwszych narratorek subkultury zapewniły im przynajmniej w pewnej części poczucie akceptacji. W niektórych przypadkach pojawiły się samookaleczenia oraz myśli samobójcze, jedna narratorka przeszła załamanie nerwowe i musiała skorzystać z pomocy psychiatry. Przynależność do subkultury nie rozwiązuje wszystkich problemów. Jak wspominał Melosik, subkultury młodzieżowe dawniej mogły odgrywać rolę odskoczni od trudów życia rodzinnego, były wtedy określoną alternatywą i zaprzeczeniem głównych ideologii i zasad, a przede wszystkim były to spójne grupy z wyraźnymi granicami, jednostki silnie się z nimi utożsamiały, właśnie do subkultury przenosiły swoje problemy. Obecnie w rozwiązywaniu problemów mogą pomóc psychiatra i psycholog. W życiu codziennym to jednostka sama musi stawić czoła trudom oraz swojej inności (Melosik, 2016, s. 92).

Poczucie odrzucenia ze strony rówieśników i rodziców może skutkować utożsamianiem się z subkulturami. Grupy subkulturowe mogą zaspokoić potrzebę akceptacji i zapełnić wolny czas. Jednak współcześnie nie są one spójnymi grupami. Ich członkowie nie utożsamiają się z nimi tak silnie, jak to bywało dawniej. Granice pomiędzy poszczególnymi subkulturami uległy rozluźnieniu. Pragnę również zwrócić uwagę, że nie powinno się wstydzić korzystania z pomocy psychiatry czy psychologa w rozwiązywaniu swoich problemów.

\section{ZAKOŃCZENIE}

Przeprowadzone przeze mnie badania pozwoliły zauważyć, że uczestnictwo w subkulturach młodzieżowych umożliwia zdobycie akceptacji. Widoczny jest częsty brak tolerancji ze strony rówieśników i rodziców wobec odmiennych zainteresowań oraz stylu. Odrzucenie przez rówieśników i brak wsparcia rodziców mogą popychać w stronę grup subkulturowych, a bycie członkiem grupy subkulturowej może wpływać negatywnie na relacje $\mathrm{z}$ rówieśnikami i rodzicami. $\mathrm{W}$ społeczeństwie funkcjonuje wiele stereotypów związanych z subkulturami.

Warto podkreślić, że nie każda subkultura wiąże się z agresywnym zachowaniem. Subkultury młodzieżowe to grupy, które pozwalają na dzielenie się swoimi zainteresowaniami czy oferują wspólne spędzanie czasu. Na zakończenie przytoczę jeszcze słowa jednej z moich narratorek, która wskazała, że należy zmierzyć 
się z postrzeganiem przez pryzmat wyglądu: Subkultura ma to do siebie, że z zewnątrz wygląda dużo gorzej, niż jest w środku.

\section{BIBLIOGRAFIA}

Bauman, Z. (2007). Tożsamość. Rozmowy z Benedetto Vecchim. Gdańsk: GWP.

Bauman, Z. (2009). Niecodzienność nasza codzienna... W: M. Bogunia-Borowska (red.), Barwy codzienności (s. 77-93). Warszawa: Wydawnictwo Scholar.

Brzezińska, A.I., Appelt, K., Ziółkowska, B. (2016). Psychologia rozwoju człowieka. Sopot: GWP.

Filipiak, M. (1999). Od subkultury do kultury alternatywnej. Wprowadzenie do subkultur młodzieżowych. Lublin: Wydawnictwo UMCS.

Giddens, A. (2010). Nowoczesność i tożsamość. Warszawa: Wydawnictwo Naukowe PWN.

Goffman, E. (2005). Piętno. Rozważania o zranionej tożsamości. Gdańsk: GWP.

Melosik, Z. (2015). Kultura popularna, pedagogika i młodzież. W: J. Pyżalski (red.), Wychowawcze i społeczno-kulturowe kompetencje współczesnych nauczycieli. Wybrane konteksty (s. 31-42). Łódź: theQ studio.

Melosik, Z. (2016). Post-subkultury i tożsamość młodzieży współczesnej: tyrania tymczasowości? Studia Edukacyjne, (39), 73-96.

Muggleton, D. (2004). Wewnątrz subkultury: ponowoczesne znaczenie stylu. Kraków: Wydawnictwo UJ.

Nikitorowicz, J. (1995). Pogranicze, tożsamość, edukacja międzykulturowa. Białystok: Trans Humana.

Pęczak, M. (1992). Mały słownik subkultur młodzieżowych. Warszawa: Wydawnictwo Naukowe Semper.

Piotrowski, P. (2003). Subkultury młodzieżowe. Aspekty psychospołeczne. Warszawa: Wydawnictwo Akademickie „Żak”.

Rosenthal, G. (2012). Badania biograficzne. W: K. Kaźmierska (red.), Metoda biograficzna w socjologii. Antologia tekstów (s. 279-308). Kraków: Zakład Wydawniczy Nomos.

Rubacha, K. (2008). Metodologia badań nad edukacja. Warszawa: Wydawnictwa Akademickie i Profesjonalne.

Tomaszek, K., Tucholska, S. (2012). Psychospołeczne następstwa poczucia alienacji u młodzieży. Pedagogia Christiana, 30(2), 163-201. DOI: https://doi.org/10.12775/PCh.2012.030

\section{SUMMARY}

The article deals with seeking acceptance by young people who are struggling with many difficulties. Problems in relationships with peers and a lack of understanding on the part of parents affects the search for acceptance outside the immediate environment. Young people seek acceptance among others from youth subcultures. They have changed significantly today. They are no longer highly visible groups with clearly defined boundaries. Changes in modern society have also affected youth subcultures. The purpose of the analysis was to look for an answer to a question that was formulated as follows: What is the sense of identity in the narratives of representatives of youth subcultures? The narrative and biographical interview method was used in these studies. The study involved five young women. In the qualitative research described here, the narrators indicated that they were struggling with difficult relationships with parents and peers, and the subculture allowed them to find understanding.

Keywords: youth subcultures; sense of acceptance; acceptance 